DOI: https://doi.org/10.18371/fp.3(43).2021.546366

УДК: 658.012.32:658.589

\title{
МОДЕЛІ СТРАТЕГІЧНОГО ПЛАНУВАННЯ ІННОВАЦІЙНОЇ ДІЯЛЬНОСТІ ПІДПРИЄМСТВА В УМОВАХ АКТИВІЗАЦІЇ МЕНТОРИНГУ
}

\author{
ДОРОШКЕВИЧ Катерина Олегівна \\ к.е.н., доиент, \\ доцент кафедри менеджменту і міжнародного підприємництвва, \\ НУ «Львівська політехніка» \\ ORCID ID: https://orcid.org/0000-0003-3966-224X
}

\section{ІВАСЮК Володимир Васильович}

к.е.н., доцент кафедри менеджменту і міжнародного підприємництва, НУ «Львівська політехніка»

ORCID ID: https://orcid.org/0000-0003-4057-5442

\section{ДЗВОНИК Роман Ярославович}

аспірант кафедри менеджменту і міжнародного підприємництва, НУ «Львівська політехніка» ORCID ID: https://orcid.org/0000-0002-1702-0775

e-mail:roman.dzvonyk@gmail.com

\section{КОВТОК Галина Іванівна}

молодший науковий співробітник НДЛ-87

кафедри менеджменту і міжнародного підприємництва, НУ «Львівська політехніка» ORCID ID: https://orcid.org/0000-0003-0533-9268

\begin{abstract}
Анотація. $У$ статті використано граф Марківського процесу для формування моделі стратегічного планування інновачійної діяльності підприємства в умовах активізаизї менторингу. Це дозволило оцінити інтенсивність менторингового впливу на учасників стратегічного планування інновачійної діяльності підприємства за допомогою рекомендованого порядку імітаційного моделювання.
\end{abstract}

Ключові слова: інноваційна діяльність, підприємства, стратегічне планування, менторинг, імітаційне моделювання, ланцююг Маркова.
Аннотация. $B$ cmamье использовань граф Марковского прочесса для формирования модели стратегчческого планирования инновационной деятельности предприятия в условиях активизации менторинга. Это позволило оценить интенсивность менторингового воздействия на участников стратегического планирования инновационной деятельности предприятия с помощуью рекомендованного порядка имитационного моделирования.

Ключевые слова: инновачионная деятельность, предприятия, стратегчческое планирование, менторинг, имитацуионное моделирование, цепь Маркова. 
Постановка проблеми. Як відомо, менторинг - це метод персоналізованого навчання та розвитку персоналу, під час якого більш досвідчений працівник (наставник, ментор) ділиться знаннями зі своїми колегами (менті) протягом певного часу. Його можна розглядати як важливий чинник стратегічно-тактичного інноваційного розвитку підприємства. Зокрема, у сфері інноваційної діяльності підприємства, наставницька діяльність (менторинг) дозволяє отримати переваги у вигляді набуття знань працівниками підприємства щодо стратегії його інноваційної діяльності; прикладного характеру набутих знань та можливості їх реалізації при досягненні стратегічних цілей; формування особистої зацікавленості працівників у реалізації стратегії інноваційної діяльності підприємства; системності мотиваційного впливу на учасників стратегічного планування тощо. На підставі цього стверджуємо, що менторинг має вплив на стратегічне планування інноваційної діяльності підприємства.

Використавши ланцюг Маркова для моделювання стратегічного планування інноваційної діяльності підприємства (стратегічне планування інноваційної діяльності підприємства представлено як сукупність взаємодіючих ідентифікаторів станів, на підставі якого сформовано граф ланцюга Маркова), як це здійснено в [1], припускаємо наступне. Менторинг впливає на перехід між станами марківської моделі стратегічного планування інноваційної діяльності підприємства, який можна виразити відповідним показником (інтенсивність менторингового впливу).

Таким чином, використання ланцюгів Маркова для дослідження процесів стратегічного планування інноваційної діяльності підприємства в умовах активізації менторингу у подальшому слід розвинути у напрямі імітаційного моделювання переходу між його етапами (станами марківської моделі) під впливом процесів менторингу, що потребує ретельного дослідження.

Аналіз останніх досліджень і публікацій. Імітаційне моделювання, як відомо, полягає у побудові моделей реальних систем та виконанні циклу експериментів із використанням цієї моделі, що дозволяє вивчити іiі поведінку та оцінити потенційні варіанти стратегії управління моделлю. Таким чином, функціональними завданнями, що вирішуються у процесі імітаційного моделювання $є$ : опис поведінки економічної моделі, побудова теорії та гіпотези для дослідження поведінки моделі, прогнозування поведінки моделі у майбутньому, ефекту від зміни у системі, методах та операціях [2]. Цей вид моделювання поширений як оптимізаційний метод прийняття рішень, вдосконалення бізнес-процесів, оцінювання багаторівневої системи управління якістю, моделювання економічного розвитку територій та чи процесів, оцінювання ефективності маркетингових комунікаційних полів тощо [3-6].

Імітаційне моделювання бізнес процесів втілює думку про те, що підприємницька діяльність $\epsilon$ серією внутрішніх процесів, які перетворюють вхідні ресурси у готовий продукт. Виходячи із цього, імітаційна модель для бізнеспроцесів реалізує дії із використання ресурсів, прийняття управлінських рішень та стохастичної поведінки в реальних ринкових умовах [7]. Водночас, у [8] узагальнені основні критерії якості для моделей бізнес-процесів: 
правильність, модель повинна бути синтаксично та семантично правильною; актуальність, модель не повинна містити недоречних деталей; економічна ефективність, модель повинна служити певній меті, яка перевищує вартість моделювання; чіткість, модель повинна бути зрозумілою для користувачів; порівнюваність, моделі повинні базуватися на одних і тих же положеннях, та забезпечити моделювання всередині та між моделями; систематичне проектування, модель повинна мати чітко визначені інтерфейси до інших типів моделей, таких як організаційні діаграми та моделі даних; простота, що полягає у використанні лише математичної моделі, яка описує функціонування системи.

Щодо порядку імітаційного моделювання, то у [9] виділено такі етапи його реалізації. Спершу слід сформувати модель, яка відображає бізнеспроцес (усі складові моделі, підпроцеси та дії слід ретельно задокументувати, вказавши взаємозв'язки між ними), далі слід ідентифікувати та призначити необхідні ресурси, які забезпечують функціонування моделі. Після перевірки правильності моделі, можна переходити до моделювання, що повинно передбачати достатню кількістю імітацій. Після завершення моделювання слід здійснити статистичну обробку результатів, що забезпечить формування раціональних управлінських рішень. Ці етапи доповнює Д.А. Имакаева, включаючи до них комп'ютерну візуалізацію ключових параметрів дослідницьких моделей та підрахунок основних характеристик для отримання даних [10]. Зважаючи на необхідність проведення достатньої кількості імітацій, комп'ютерна візуалізація та автоматизація розрахунків при імітаційному моделювання є доречною.

Отже, використання імітаційного моделювання при стратегічному плануванні діяльності підприємства в умовах інноваційного розвитку не висвітлено у літературних джерелах. Проте, наведені вище рекомендації щодо формування імітаційних моделей, послідовності моделювання тощо можна використати 3 метою підвищення рівня стратегічного планування інноваційної діяльності підприємства в умовах активізації менторингу.

Переваги імітаційного моделювання розкриті у працях [11-13]. Вони полягають у: можливості здійснення комп'ютерних експериментів, що покращують якість моделі; виявленні динамічних змін у поведінці системи, що виникає при повторних імітаційних експериментах; спостереженні за окремими складовими (елементами) моделі; вимірюванні впливу виявлених змін на результативність моделі; виявлення ефектів взаємодії між елементами; об'єктно-орієнтованому проектуванні та застосуванні високотехнологічних рішень при побудові комп'ютерних моделей; зниженні ризиків невдач при побудові бізнес процесів тощо; прогнозуванні поведінки бізнесу при найменших змінах і відхиленнях, які можуть спричинити за собою не малі втрати грошей або інших ресурсів.

Щодо недоліків, то у [14] вказано на те, що запропоновані авторами імітаційні та математичні моделі не завжди теоретично обгрунтовані і емпірично апробовані, що впливає на результативність їх використання в дослідженнях промисловості. Переваги і недоліки імітаційного моделювання узагальнені табл. 1. 
Таблиця 1

Переваги і недоліки імітаційного моделювання

\begin{tabular}{|c|c|}
\hline \multicolumn{2}{|c|}{ Імітаційне моделювання } \\
\hline Переваги & Недоліки \\
\hline $\begin{array}{l}\text { Можливість здійснення комп'ютерних експери- } \\
\text { ментів, що покращують якість моделі }\end{array}$ & $\begin{array}{l}\text { Труднощі при теоретичному обгрунту- } \\
\text { ванні математичних та імітаційних моделей, } \\
\text { що впливає на результативність їх викорис- } \\
\text { тання }\end{array}$ \\
\hline $\begin{array}{l}\text { Здатність виявляти динамічні зміни у поведінці } \\
\text { системи, що виникає при повторних імітаційних } \\
\text { експериментах }\end{array}$ & $\begin{array}{l}\text { Зниження достовірності імітаційних до- } \\
\text { сліджень за відсутності емпіричної апроба- } \\
\text { ції моделей }\end{array}$ \\
\hline $\begin{array}{l}\text { Спостереження за окремими складовими (еле- } \\
\text { ментами) моделі у ході імітаційних експериментів }\end{array}$ & $\begin{array}{l}\text { Висока трудомісткість обчислень за від- } \\
\text { сутності комп'ютерних засобів обробки да- } \\
\text { них }\end{array}$ \\
\hline $\begin{array}{l}\text { Вимірювання впливу виявлених динамічних } \\
\text { змін на результативність моделі шляхом статисти- } \\
\text { чної обробки даних }\end{array}$ & \\
\hline $\begin{array}{l}\text { Виявлення ефектів взаємодії між елементами } \\
\text { моделі при іiі обгрунтуванні }\end{array}$ & \\
\hline $\begin{array}{l}\text { Об'єктно-орієнтоване проектування та застосу- } \\
\text { вання високотехнологічних рішень при побудові } \\
\text { комп'ютерних моделей }\end{array}$ & \\
\hline $\begin{array}{l}\text { Зниження ризиків невдач при побудові бізнес- } \\
\text { процесів та прогнозування поведінки бізнес- } \\
\text { одиниць при найменших змінах і відхиленнях, які } \\
\text { можуть спричинити за собою не малі втрати гро- } \\
\text { шей або інших ресурсів }\end{array}$ & \\
\hline
\end{tabular}

Джерело: складено авторами на основі [11-14]

Метою статті $\epsilon$ вивчення перебігу станів стратегічного планування під дією зовнішніх чинників впливу i інноваційного розвитку та здійснення його моделювання в умовах активізації менторингу, із використанням імітаційного моделювання.

Виклад основного матеріалу дослідження. Дослідимо перебіг станів стратегічного планування під зміною зовнішніх чинників впливу на його процеси в умовах інноваційного розвитку (рис. 1).

Гіпотеза щодо можливості переходу між станами марківської моделі під вПливом чинників інтенсивності інформаційних потоків використана при моделюванні соціально-екологоекономічної системи К.Ю. Романовою
[15]. Автором розглянуто соціальноеколого-економічну систему як складну, нелінійну, самоорганізуючу систему, що складається 3 трьох частин, кожна 3 яких також відноситься до складних самоорганізуючих систем. Вони характеризуються інформаційними властивостями, самоузгодженістю іiі складових частин. На думку автора, цінна та зареєстрована інформація виконує функціональну і керуючу роль у такій системі. Це дозволило при іiї моделюванні використати математичний апарат марківських випадкових процесів (безперервний ланцюг Маркова) та пов'язати перехід між станами моделі із інтенсивністю потоків інформації. 
В умовах активізації менторингової діяльності, що забезпечує цілеспрямований наставницький вплив на працівників підприємства 3 метою стратегічного навчання, передачі знань щодо стратегії підприємства та підтримки прийняття стратегічних рішень тощо, перехід етапами стратегічного плану- вання (графу ланцюга Маркова для стратегічного планування інноваційної діяльності підприємства, що сформований у [1]) залежить від інтенсивності менторингового впливу.

Це може бути відображено у розподіленому графі Марківської моделі (рис. 1).

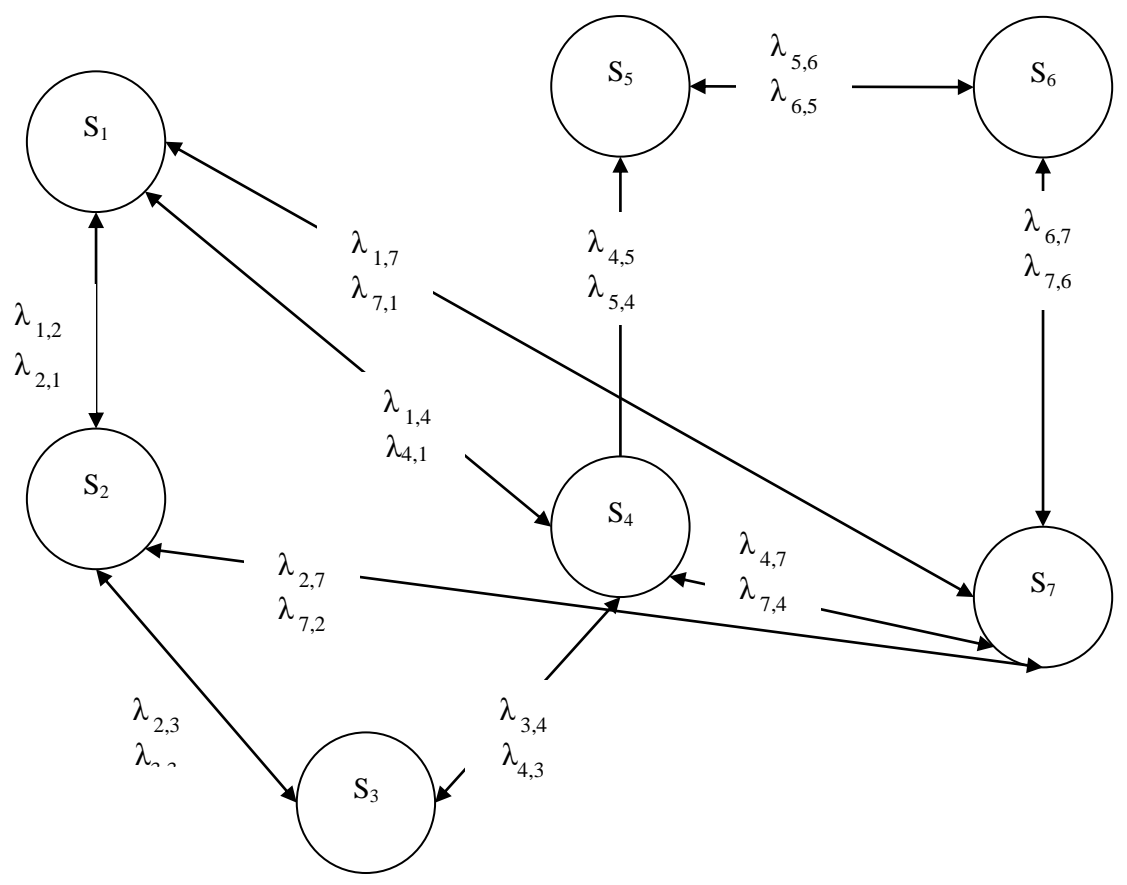

Рис. 1. Розподілений граф Марківської моделі стратегічного планування інноваційної діяльності підприємства в умовах активізації менторингу

Примітка: $\lambda_{i j}, \lambda_{j i}$ - інтенсивність менторингового впливу на учасників стратегічного планування підприємства; $\mathrm{S}_{1}$ - директор підприємства; $\mathrm{S}_{2}$ - стратегічний директор; $\mathrm{S}_{3}$ - стратегічні альтернативи, інструментарій вибору стратегії; $\mathrm{S}_{4}$ - стратегія підприємства; $\mathrm{S}_{5}$ - лінійні керівники; $\mathrm{S}_{6}$ - працівники підприємства; $\mathrm{S}_{7}$ - стратегічні плани.

Джерело: складено авторами на основі [1]

Для визначення імовірності станів, перехід між якими (процеси оновлення) залежить від рівня менторингового впливу на учасників стратегічного планування підприємства слід використати рівняння Колмогорова (1) [15, 16]. Для його формування застосовує- мо алгоритм, що наведений у Е. С. Вентцель, та модифікуємо його відповідно до структури розподіленого графу Марківської моделі стратегічного планування інноваційної діяльності підприємства в умовах активізації менторингу (рис.

1) [17]: 


$$
\left\{\begin{aligned}
\frac{d P_{1}}{d t}= & \lambda_{21} P_{2}+\lambda_{41} P_{4}+\lambda_{71} P_{7}-\left(\lambda_{12}+\lambda_{14}+\lambda_{17}\right) P_{1} ; \\
\frac{d P_{2}}{d t}= & \lambda_{12} P_{1}+\lambda_{32} P_{3}+\lambda_{72} P_{7}-\left(\lambda_{21}+\lambda_{23}+\lambda_{27}\right) P_{2} ; \\
& \frac{d P_{3}}{d t}=\lambda_{23} P_{3}+\lambda_{43} P_{4}-\left(\lambda_{32}+\lambda_{34}\right) P_{3} ; \\
\frac{d P_{4}}{d t}= & \lambda_{14} P_{1}+\lambda_{54} P_{5}+\lambda_{74} P_{7}-\left(\lambda_{41}+\lambda_{45}+\lambda_{47}\right) P_{4} ; \\
& \frac{d P_{5}}{d t}=\lambda_{45} P_{4}+\lambda_{65} P_{6}-\left(\lambda_{54}+\lambda_{56}\right) P_{5} ; \\
& \frac{d P_{6}}{d t}=\lambda_{56} P_{5}+\lambda_{76} P_{7}-\left(\lambda_{65}+\lambda_{67}\right) P_{6} ; \\
\frac{d P_{7}}{d t}= & \lambda_{17} P_{2}+\lambda_{47} P_{4}+\lambda_{67} P_{6}-\left(\lambda_{71}+\lambda_{74}+\lambda_{76}\right) P_{7} ;
\end{aligned}\right.
$$

Як відомо, сума всіх імовірностей рівна 1, що описує рівняння перехідних станів марківського графу

$$
P_{1}+P_{2}+P_{3}+P_{4}+P_{5}+P_{6}+P_{7}=1
$$

Воно додане до системи незалежних рівнянь Колмогорова, кожне із яких містить рівняння імовірності станів марківського графу в умовах активізації менторингу, що рівне сумі отриманих імовірностей усіх станів (з яких ідуть стрілки в даному стані розподіленого графу на рис. 1) та інтенсивності відповідних потоків подій, мінус сумарна інтенсивність всіх потоків, що виводять систему із відповідного стану, помножені на їх імовірності ( $i$ го стану).

Для розв'язку системи рівнянь (2) слід задати інтенсивність менторингового впливу на учасників стратегічного планування підприємства, яку рекомендуємо оцінити у діапазоні $[0 ; 1]$. Для цього застосуємо імітаційне моделювання та використаємо такий порядок (рис. 2):

1. Визначення цілей і завдань імітаційного моделювання інтенсивності менторингового впливу на учасників стратегічного планування підприємства. Даний етап передбачає висунення основних припущень моделі, виявлення типів залежності випадкової величини, законів розподілу та статистичних характеристик змінних. Нами висунуто припущення відносно того, що інтенсивність менторингового впливу на учасників стратегічного планування на підприємстві може бути виявлена у результаті імітаційного моделювання. Ця величина має нормальний закон розподілу, змінюється у діапазоні [0;1]. Математичне сподівання даної величини $\left(\overline{\lambda_{\jmath}}, \overline{\lambda_{\imath \jmath}}\right)$ та середньоквадратичне відхилення $\left(\sigma^{2}\right)$ підлягають розрахунку у результаті серії імітаційних експериментів;

2. Інформаційне забезпечення імітаційного моделювання інтенсивності менторингового впливу на учасників стратегічного планування підприємства полягає у підготовці до використання інформації для імітаційного моделювання інтенсивності менторингового впливу на стратегічне планування підприємства. Пріоритет у процесі реалізації даного етапу має інформація 
щодо процесів стратегічного планування, що вказує на стани процесів стратегічного планування, їх взаємозв'язки, перехід між станами тощо.

3. Визначення методів та засобів імітаційного моделювання. Нами обрано використання EXCEL функції СЛЧИС(), яка дозволяє отримати рівномірно розподілене випадкове число у діапазоні [0;1], що може виражати інтенсивність менторигового впливу.

4. Проведення серії імітаційних прогонів (імітацій), у результаті кожної із яких отримаємо значення $\lambda_{j i}, \lambda_{i j}$.

5. Узагальнення результатів імітаційних прогонів, визначення середніх значень інтенсивності менторингового впливу на учасників стратегічного планування підприємства $\left(\overline{\lambda_{\jmath l}}, \overline{\lambda_{l \jmath}}\right)$.

6. Розрахунок імовірності переходу між дискретними станами моделі стратегічного планування інноваційної діяльності підприємства під дією чинника активізації менторингової діяльності (система рівнянь 2), використовуючи середні значення інтенсивності менторингового впливу на учасників стратегічного планування підприємства $\left(\overline{\lambda_{\jmath l}}, \overline{\lambda_{l \jmath}}\right)$.

7. Узагальнення результатів та прийняття управлінських рішень.

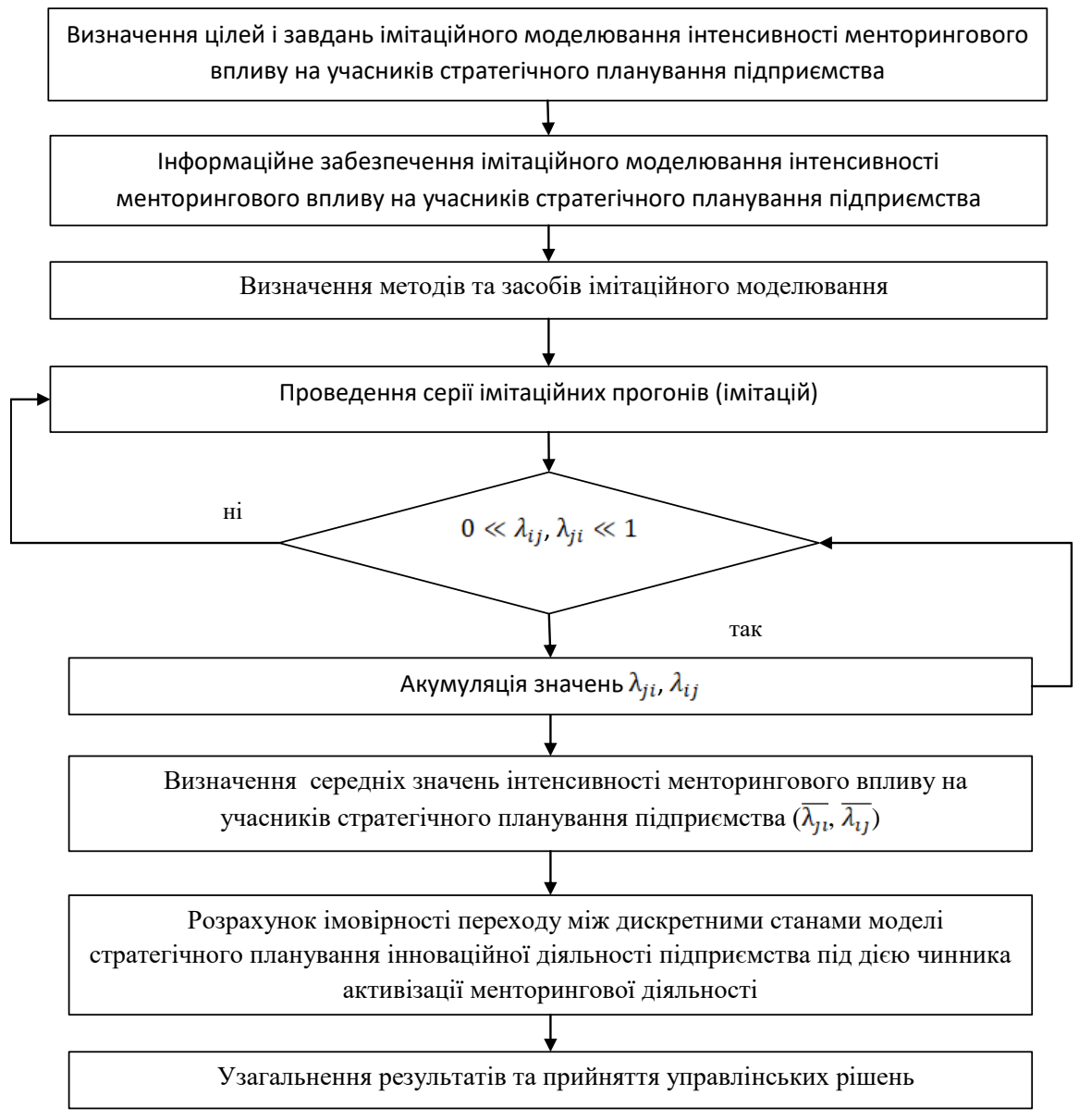

Рис. 2. Порядок імітаційного моделювання з метою виявлення інтенсивності менторингового впливу на стратегічне планування підприємства Джерело: складено авторами

Використаємо розроблений порядок (рис. 2) для імітаційного моделювання інтенсивності менторингового впливу на стратегічне планування ТВК 
«Львівхолод», що виконане за допомогою EXCEL. На підприємстві існує позитивний досвід менторингової діяльності. Протягом останніх років ментори здійснюють наставництво своїх нових колег, проте ця діяльність характерна не для усіх сфер діяльності підприємства та застосовується переважно у збуті. Компанії належить мережа магазинів самообслуговування «Рукавичка» (129 магазинів), а також виробничі потужності, лабораторія, власний логістичний центр. Саме на ці об'єкти спрямується менторинговий вплив з метою підвищення їх результативності та отримання мотиваційних ефектів. Щодо стратегічного планування, то менторинг у ТВК «Львівхолод» не має системних властивостей, до нього не залучені усі учасники процесів стратегічного планування. Тому, розглянемо можливість удосконалення процесів стратегічного планування ТВК «Львівхолод» в умовах активізації менторингу. Мотиваційна політика підприємства передбачає заходи щодо прямої і опосередкованої матеріальної мотивації, нематеріальну мотивацію. Навчання працівників за рахунок компанії разом із оплатою мобільного телефону, матеріальної допомогою, оплатою бензину є складовими системи опосередкованої матеріальної мотивації. У компанії застосовується в основному преміальна система оплати праці, що допускає нарахування премії до місячних (посадових) окладів працівників під час виконання відповідних виробничих показників.

Результати моделювання виражені у середніх значеннях інтенсивності менторингового впливу на учасників стратегічного планування ТВК «Львівхолод» $\left(\overline{\lambda_{\jmath}}, \overline{\lambda_{\imath \jmath}}\right)$, відображені в табл. 2.

3 урахуванням отриманих результатів, рівняння (2) набуло вигляду:

$$
\left\{\begin{array}{c}
1,55 P_{1}=0,53 P_{2}+0,46 P_{4}+0,51 P_{7} \\
1,53 P_{2}=0,51 P_{1}+0,51 P_{3}+0,47 P_{7} \\
0,96 P_{3}=0,51 P_{3}+0,46 P_{4} \\
1,46 P_{4}=0,58+0,8 P_{5}+0,48 P_{7} \\
0,99 P_{5}=0,5 P_{4}+0,51 P_{6} \\
1,02 P_{6}=0,53 P_{5}+0,52 P_{7} \\
1,44 P_{7}=0,48 P_{2}+0,52 P_{4}+0,5 P_{6}
\end{array}\right.
$$

Для розв'язку системи рівнянь (4), скористаємось онлайн-сервісами (https://matrixcalc.org/slu.html). Для цього слід відкинути останнє рівняння та замість нього додати рівність (3).

У результаті отримаємо наступні значення імовірності переходу між дискретними станами моделі стратегічного планування інноваційної діяльності ТВК «Львівхолод» під дією чин- ника активізації менторингової діяльності:

$P_{1}=-0,182 ; P_{2}=-0,557 ; P_{3}=$ 0,$505 ; P_{4}=0,208$

$P_{5}=0,355 ; P_{6}=0,374 ; P_{7}=0,297$.

Як бачимо, імовірності переходу від станів $\mathrm{S}_{1}$ та $\mathrm{S}_{2}$ є від'ємними. Незважаючи на те, що у класичній теорії, імовірності можуть бути визначені лише позитивним значення змінної (сума 
усіх імовірностей станів рівна одиниці, що враховано нами при вирішенні системи рівнянь), негативне значення пояснимо 3 позицій відмови від реалі- зації відповідних етапів стратегічного планування.

Таблиця 2

Середні значення інтенсивності менторингового впливу на учасників стратегічного планування ТВК «Львівхолод»

\begin{tabular}{|c|c|c|c|}
\hline № прогону & Середні значення & № прогону & Середні значення \\
\hline$\lambda_{12}$ & 0,48 & $\lambda_{72}$ & 0,49 \\
\hline$\lambda_{21}$ & 0,52 & $\lambda_{34}$ & 0,51 \\
\hline$\lambda_{13}$ & 0,50 & $\lambda_{43}$ & 0,48 \\
\hline$\lambda_{31}$ & 0,49 & $\lambda_{35}$ & 0,51 \\
\hline$\lambda_{14}$ & 0,51 & $\lambda_{53}$ & 0,46 \\
\hline$\lambda_{41}$ & 0,47 & $\lambda_{36}$ & 0,46 \\
\hline$\lambda_{15}$ & 0,52 & $\lambda_{63}$ & 0,52 \\
\hline$\lambda_{51}$ & 0,46 & $\lambda_{37}$ & 0,55 \\
\hline$\lambda_{16}$ & 0,54 & $\lambda_{73}$ & 0,55 \\
\hline$\lambda_{61}$ & 0,46 & $\lambda_{45}$ & 0,47 \\
\hline$\lambda_{17}$ & 0,52 & $\lambda_{54}$ & 0,49 \\
\hline$\lambda_{71}$ & 0,45 & $\lambda_{46}$ & 0,52 \\
\hline$\lambda_{23}$ & 0,51 & $\lambda_{64}$ & 0,52 \\
\hline$\lambda_{32}$ & 0,45 & $\lambda_{47}$ & 0,58 \\
\hline$\lambda_{24}$ & 0,52 & $\lambda_{74}$ & 0,48 \\
\hline$\lambda_{42}$ & 0,46 & $\lambda_{56}$ & 0,49 \\
\hline$\lambda_{25}$ & 0,48 & $\lambda_{65}$ & 0,48 \\
\hline$\lambda_{52}$ & 0,50 & $\lambda_{57}$ & 0,44 \\
\hline$\lambda_{26}$ & 0,46 & $\lambda_{75}$ & 0,49 \\
\hline$\lambda_{62}$ & 0,50 & $\lambda_{67}$ & 0,52 \\
\hline$\lambda_{27}$ & 0,47 & $\lambda_{76}$ & 0,49 \\
\hline
\end{tabular}

Джерело: розраховано авторами за допомогою EXCEL

Розглянемо отримані результати. Отже, дія щодо делегування директором підприємства повноважень із стратегічного планування своєму підлеглому (у моделі це стратегічний директор, що відповідає операції 1) згідно отриманих результатів може бути відмінена. Уважаємо це твердження доречним, адже на багатьох підприємствах (особливо малих) стратегічне планування здійснюється безпосередньо самим директором. В умовах активізації чинника менторингу, директор підприємства може не погоджуватись на делегування повноважень із стратегічного планування, що викли- кано глибшою співпрацею із підлеглими та досвідом їх персоналізованого навчання тощо. Наступна операція графу марківської моделі стратегічного планування передбачає те, що стратегічний директор формує, та оцінює стратегічні альтернативи, обгрунтовує інструментарій вибору стратегії. Зважаючи на те, що посада стратегічного директора (інші аналогічні посади) може не бути створена на підприємстві, або директор може відмовитись від делегування повноважень щодо стратегічного планування, що вказує на можливість відміни попередньої операції, ця дія також може бути 
скасована. Окрім цього, директор підприємства може самостійно обирати та затверджувати стратегію розвитку підприємства, використовуючи при цьому свій власний інструментарій. Далі, усі етапи розподіленого графу марківської моделі стратегічного планування підприємства мають різні імовірності переходу між етапами. Найбільша із них спостерігається на етапі 3, що передбачає вибір стратегії діяльності підприємства. Під дією чинника менторингу відбувається поширення знань щодо місії і цілей організації, активізується діяльність щодо iii розвитку, формуються погляди щодо змін у діяльності підприємства, відбувається мотиваційний вплив тощо. Ці процеси полегшують вибір стратегії поведінки підприємства, знижують ризик прийняття нераціональних управлінських рішень. Інші етапи (поширення знань щодо стратегії лінійним керівникам, їх керівництво працівниками підприємства та виконання стратегічних планів тощо) мають меншу імовірність реалізації в умовах активізації менторингу.

Висновки. Використання графу Марківського процесу (ланцюга Маркова, що відображає сукупність взаємодіючих ідентифікаторів станів) дозволило сформувати модель стратегічного планування інноваційної діяльності підприємства. Проте в умовах активізації менторингу перехід між станами моделі залежить від інтенсивності менторингового впливу на учасників стратегічного планування інноваційної діяльності підприємства, що підлягає оцінюванню. Це можливо реалізувати за допомогою порядку імітаційного моделювання, який містить такі етапи: визначення цілей і завдань імітаційного моделювання інтенсивності менторингового впливу на учасників стратегічного планування підприємства; інформаційне забезпечення імітаційного моделювання інтенсивності менторингового впливу на учасників стратегічного планування підприємства; визначення методів та засобів імітаційного моделювання; проведення серії імітаційних прогонів (імітацій); акумуляція значень; визначення середніх значень інтенсивності менторингового впливу на учасників стратегічного планування підприємства; розрахунок імовірності переходу між дискретними станами моделі стратегічного планування інноваційної діяльності підприємства під дією чинника активізації менторингової діяльності; узагальнення результатів та прийняття управлінських рішень.

\section{Список використаної літератури}

1. Doroshkevych K., Maslak O., Voronovska M. \& Salata I. (2020). Use of Markov chains for modeling processes of strategic planning of innovative activity of the enterprise. WSEAS Transactions on Environment and Development, 16, 440-447.

2. Robert E. Shannon (1992). Introduction to simulation. WSC '92: Proceedings of the 24th conference on Winter simulation, 65-73, doi: https://doi.org/10.1145/167293.167302. 
3. Davenport T. H. (1993). Process innovation : reengineering work through information technology. Harvard Business School Press, Boston.

4. Paul R. J., Giaglis G. M. \& Hlupic V. (1999). Simulation of Business Processes. The American Behavioral Scientist, 42(10), 1551-1576.

5. De Vreede G.J., Verbraeck A. \& Van Eijck D.T.T. (2003). Integrating the Conceptualization and Simulation of Business Processes: A Modelling Method and an Arena Template. Simulation, 79(1), 43-55.

6. Машкова А.Л., Савина О.А., Маматов А.В., Новикова Е.В. Компьютерное моделирование процессов экономической динамики в отраслевом разрезе. Известия Юго-Западного государственного университета. 2018. Т. 22. № 5. С. 96-108. doi: 10.21869/2223-1560-2018-22-5-96-10

7. Tumay K. (1996). Business process simulation. Proceedings Winter Simulation Conference, p. 93-97. doi: 10.1109/WSC.1996.873265 8-11.

8. Becker J., Kugeler M. \& Rosemann M. (2003). Process Management - A guide for the design of business processes. Springer-Verlag: Berlin.

9. Jansen-Vullers M. H. \& Netjes M. (2006). Business Process Simulation - A Tool Survey Seventh Workshop and Tutorial on Practical Use of Coloured Petri Nets and the CPN Tools Aarhus, Denmark, p. 80-101.

10. Имакаева Д. А. Имитационное моделирование при экономической оптимизации. Проблемы экономики и юридической практики. 2017. № 4. С. 11-14.

11. Marvel J. H. \& Standridge Ch. R. (2009). Simulation-enhanced lean design process. Journal of Industrial Engineering and Management, 2 (1), doi:10.3926/jiem.2009.v2n1.p90-113.

12. Скородумов П. В. (2015) Имитационное моделирование экономических систем: програмніе средства и направления их совершенствования. Проблемы развития территории. Вып 2 (76). С. 62-72.

13. Jagadeesh Chandra Bose, R. P., van der Aalst, W. M. P., Zliobaite I. \& Pechenizkiy M. (2011). Handling Concept Drift in Process Mining. International Conference on Advanced Information Systems Engineering (Caise 2011), volume 6741 of Lecture Notes in Computer Science, p. 391-405.

14. Кислицын Е. В., Городничев В. В. (2021). Имитационное моделирование развития отдельных отраслей тяжелой промышленности. Бизнес-информатика. T. 15. № 1. С. 59-77. doi:10.17323/2587-814X.2021.1.59.77.

15. Романова Е. Ю. Марковская модель самоорганизующейся социо-экологоэкономической системы с учетом переходов в различные состояния под дей- 
ствием информационных потоков. Вестник Брянского государственного технического университета. 2018. № 5(66). С. 51-55.

16. Shpak N., Odrekhivskyi M., Doroshkevych K. \& Sroka W. (2019). Simulation of Innovative Systems under Industry 4.0 Conditions. Social Sciences, 8: 7, 202. doi: https://doi.org/10.3390/socsci8070202.

17. Вентцель Е. С. Исследование операций. Задачи, принципы, методология. М.: Высш. Шк, 2001. 208 с. 